Article

\title{
Design of a Nickel-Based Bond-Coat Alloy for Thermal Barrier Coatings on Copper Substrates
}

\author{
Torben Fiedler *, Tatiana Fedorova, Joachim Rösler and Martin Bäker \\ Institute for Materials, Technische Universität Braunschweig, Langer Kamp 8, \\ 38106 Braunschweig, Germany; E-Mails: t.fedorova@tu-bs.de (T.F.); j.roesler@tu-bs.de (J.R.); \\ martin.baeker@tu-bs.de (M.B.)
}

* Author to whom correspondence should be addressed; E-Mail: t.fiedler@tu-bs.de; Tel.: +49-531-391-3063.

External Editor: Anders E. W. Jarfors

Received: 15 September 2014; in revised form: 22 October 2014 / Accepted: 23 October 2014 / Published: 6 November 2014

\begin{abstract}
To increase the lifetime of rocket combustion chambers, thermal barrier coatings (TBC) may be applied on the copper chamber wall. Since standard TBC systems used in gas turbines are not suitable for rocket-engine application and fail at the interface between the substrate and bond coat, a new bond-coat material has to be designed. This bond-coat material has to be chemically compatible to the copper substrate to improve the adhesion and needs a coefficient of thermal expansion close to that of copper to reduce thermal stresses. One approach to achieve this is to modify the standard NiCrAlY alloy used in gas turbines by adding copper. In this work, the influence of copper on the microstructure of NiCrAlY-alloys is investigated with thermodynamical calculations, optical microscopy, SEM, EDX and calorimetry. Adding copper leads to the formation of a significant amount of $\beta$-NiAl and $\alpha$-Cr. Reducing the aluminum and chromium content leads furthermore to a two-phase fcc microstructure.
\end{abstract}

Keywords: thermal barrier coatings; $\mathrm{CuNiCrAl}$; rocket engine; copper nickel chromium aluminum; CTE; Thermo-Calc 


\section{Introduction}

The combustion chamber in rocket engines has to withstand high thermomechanical loads. To cool down the chamber wall, it is usually made out of a $\mathrm{Cu}$-alloy with high thermal conductivity. Although the material is chilled inside by liquid hydrogen in cooling channels, surface-temperatures of more than $800^{\circ} \mathrm{C}$ are reached [1]. This load may cause damage due to the so-called dog-house-effect [2,3], which is caused by high internal pressure in the cooling channels, thermomechanical fatigue and creep mechanisms. One idea to avoid this damage is to lower the surface temperature of the copper alloy by applying thermal barrier coatings (TBC).

In previous studies, several types of coatings for rocket engines have been tested on copper substrates. Ogbuji et al. [4] used a $\mathrm{Cu} / \mathrm{Cr}$ coating to protect the combustion-chamber material $\mathrm{Cu}-8 \% \mathrm{Cr}-5 \% \mathrm{Nb}$. The coatings showed a lifetime of $10 \mathrm{~h}$ at a $\mathrm{Cr}$ content of $21 \%$. A NiCrAlY top-coat was investigated by Raj et al. [5] using a $\mathrm{Cu} / \mathrm{Cr}$ bond-coat on a $\mathrm{Cu}-8 \% \mathrm{Cr}-4 \% \mathrm{Nb}$ substrate. The coatings were thermally cycled in a $\mathrm{H}_{2} / \mathrm{O}_{2}$-flame. They showed no failure after 40 cycles, although large internal stresses were calculated with finite element analysis. In Schloesser et al. [6], a standard TBC-system used in gas-turbines on $\mathrm{Ni}$-substrates has been tested. It consists of a ceramic yttrium stabilized zirconia top-coat (TC) and a Ni-22\% Cr-10\%Al-1\% Y bond-coat (BC). It was found that a chemical gradient and the mismatch of thermal expansion cause damage at the substrate/BC-interface, although the typical failure in gas-turbines takes place at the $\mathrm{BC} / \mathrm{TC}$-interface.

Since the main failure in the previous research took place at the substrate/bond-coat interface, while the top-coat showed no significant failure, further research has to focus on the development of new bond-coat materials. The main goal is to reduce the dissimilarity in chemical composition and the mismatch in the coefficient of thermal expansion (CTE) between bond coat and substrate. The mean CTE (related to room temperature) of the typically used NiCrAlY alloys is about $14 \times 10^{-6} \mathrm{~K}^{-1}$ at $600{ }^{\circ} \mathrm{C}$ and $800^{\circ} \mathrm{C}[7,8]$ and $18 \times 10^{-6} \mathrm{~K}^{-1}\left(600^{\circ} \mathrm{C}\right)$, respectively, $20 \times 10^{-6} \mathrm{~K}^{-1}\left(800^{\circ} \mathrm{C}\right)$ for copper [8-10]. The mismatch in the CTE here is about $5 \times 10^{-6} \mathrm{~K}^{-1}$, while the CTE of Ni-based superalloys usually used in gas-turbines does not differ by more than $0.1 \times 10^{-6} \mathrm{~K}^{-1}$ [11] from the CTE of the bond-coat alloy.

One approach to lower the CTE mismatch and the chemical dissimilarity is to add copper to the NiCrAlY bond-coat alloy, based on the concepts proposed in [12]. Since there is no data available for $\mathrm{Cu}-\mathrm{NiCrAlY}$ alloys, the binary alloy $\mathrm{Ni}-\mathrm{Cu}$ was considered for the first evaluation. The $\mathrm{Ni}-30 \% \mathrm{Cu}$ alloy was found to have a mean CTE of $16 \times 10^{-6} \mathrm{~K}^{-1}$ at $600{ }^{\times} \mathrm{C}$ and $17 \times 10^{-6} \mathrm{~K}^{-1}$ at $800^{\circ} \mathrm{C}$ [8], which is only about $2 \times 10^{-6} \mathrm{~K}^{-1}$ lower than the CTE of copper. Although a $\mathrm{Cu}$-content higher than $30 \%$ leads to a CTE more similar to the CTE of the copper substrate, it will lower the melting temperature and the strength of the alloy.

In this paper, the influence of copper in $\mathrm{NiCrAl}$ alloys is investigated at a copper content of $30 \%$. The commonly-used NiCrAlY alloy with a Cr content of $22 \%$ and an $\mathrm{Al}$ content of $10 \%$ is chosen as a reference alloy. This alloy consists of the high-temperature phases $\gamma$ and $\beta$ and the low-temperature phases $\gamma^{\prime}$ and $\alpha$. The $\gamma$-phase is a Ni-rich fcc-crystal; $\gamma^{\prime}$ is a fcc superlattice of the $\gamma$-phase with the stoichiometry $\mathrm{Ni}_{3} \mathrm{Al}$ in the binary system; while in the ternary $\mathrm{Ni}-\mathrm{Cr}$-Al-system, the chromium is able to substitute both, the $\mathrm{Al}$ and the $\mathrm{Ni}$ atom. The $\beta$-phase is an intermetallic cubic structure with the stoichiometry $\mathrm{NiAl}$ in the binary $\mathrm{Ni}$-system, and $\alpha$ is a cubic chromium rich phase [13-16]. 
In this work, possible phase compositions are calculated with CALPHADcalculations. Based on the calculations, different alloys are chosen for further investigation. These alloys are examined metallographically and with calorimetric measurements to compare the observed microstructure with the calculations. A similar approach was used previously to study the influence of Fe [15].

\section{Results and Discussion}

To compare the results in this work with a well-known alloy system, the alloy $\mathrm{Ni}-22 \% \mathrm{Cr}-10 \% \mathrm{Al}$ was chosen as a reference, based on the work of Schloesser in previous studies [6], where the alloy $\mathrm{Ni}-22 \% \mathrm{Cr}-10 \% \mathrm{Al}-1 \% \mathrm{Y}$ has been used as a bond-coat material on copper substrates. The alloy there contains yttrium, which improves the adhesion of the aluminum oxide layers and leads to an improved cyclic oxidation behavior. This effect is not of crucial importance in rocket engines due to the short time of hot-gas exposure compared to gas-turbine application [14], and consequently, Yttrium is not considered here. The microstructure of a similar alloy $\mathrm{Ni}-20 \% \mathrm{Cr}-12 \% \mathrm{Al}$ has been studied by Achar et al. [20].

Figure 1. Calculated phase composition of the reference alloy $\mathrm{Ni}-22 \% \mathrm{Cr}-10 \% \mathrm{Al}$ and the reference alloy after adding $30 \% \mathrm{Cu}(\mathrm{Ni}-30 \% \mathrm{Cu}-22 \% \mathrm{Cr}-10 \% \mathrm{Al}) . \quad(\mathbf{a}) \mathrm{Ni}-22 \% \mathrm{Cr}-10 \% \mathrm{Al}$ (a similar result was published in [15]); (b) Ni-30\%Cu-22\%Cr-10\%Al.

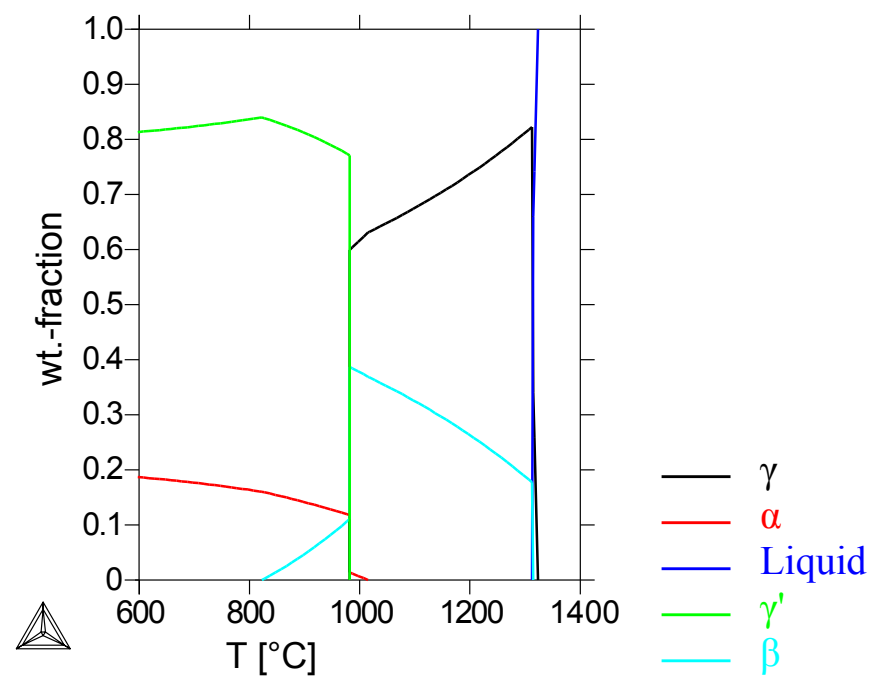

(a)

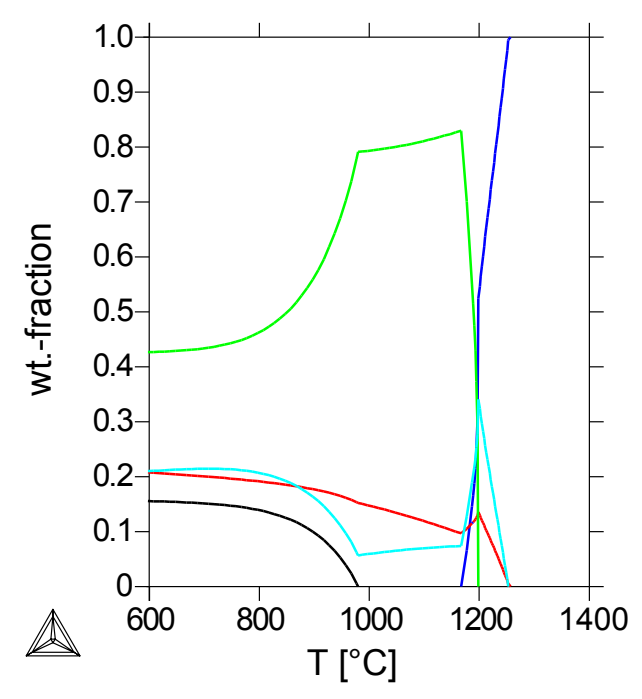

(b)

Figure 1(a) shows the calculated phase-composition of the reference alloy. At the homogenization temperature of $1000^{\circ} \mathrm{C}$, a composition of $35 \%$ cubic $\beta-\mathrm{NiAl}$ and $65 \%$ fcc $\gamma-\mathrm{Ni}$ is calculated. Below $980^{\circ} \mathrm{C}$, the formation of a bcc $\alpha$-Cr- and an fcc $\gamma^{\prime}$-phase is calculated; the $\beta$ phase is still present with a fraction of $11 \mathrm{wt} \%$. The calculated $\beta$ mass-fraction decreases at temperatures lower than $980{ }^{\circ} \mathrm{C}$. At the heat-treatment temperature of $800^{\circ} \mathrm{C}$, the calculated composition of the alloy is only $\gamma^{\prime}$ and $\alpha$-Cr. The calorimetric measurements (Figure 2) showed good agreement with the calculations. Here, the phase-reaction temperature was measured at $985^{\circ} \mathrm{C}$ and differs only by $5 \mathrm{~K}$ from the calculated temperature. The measured solidus temperature is $1295^{\circ} \mathrm{C}$ and differs only by $10 \mathrm{~K}$ from the calculated solidus temperature of $1305^{\circ} \mathrm{C}$. 
Figure 2. Calorimetric measurement data for the reference alloy $\mathrm{Ni}-22 \% \mathrm{Cr}-10 \% \mathrm{Al}$ : heating curve after homogenization.

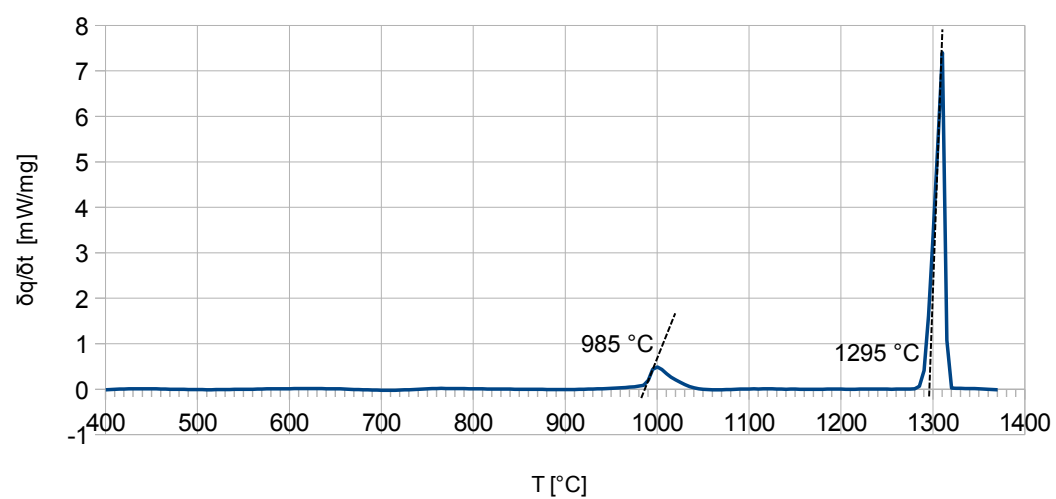

Figure 3. Optical micrographs of the reference-alloy $\mathrm{Ni}-22 \% \mathrm{Cr}-10 \% \mathrm{Al}$ after different heat treatments. The samples were quenched in water after each heat treatment and were not etched in this picture. (a) Homogenization $\left(1000^{\circ} \mathrm{C}, 4 \mathrm{~h}\right)$; (b) $800^{\circ} \mathrm{C}, 4 \mathrm{~h}$; (c) $800^{\circ} \mathrm{C}, 100 \mathrm{~h}$.

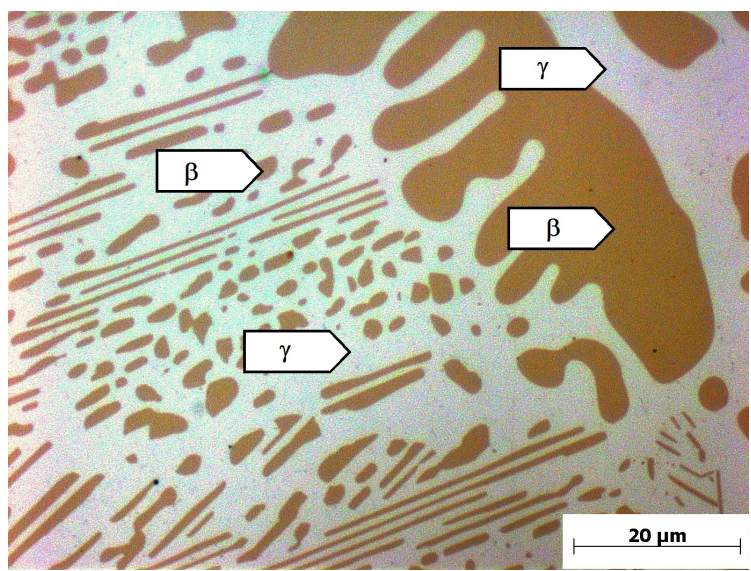

(a)

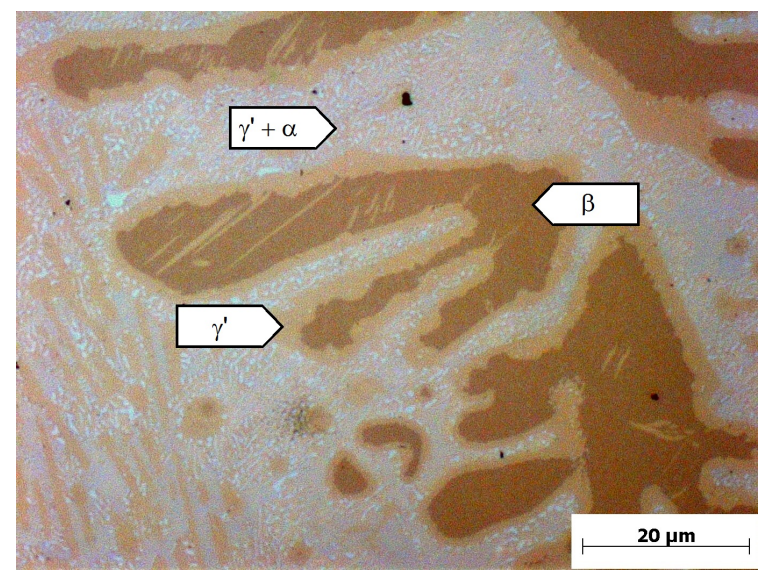

(b)

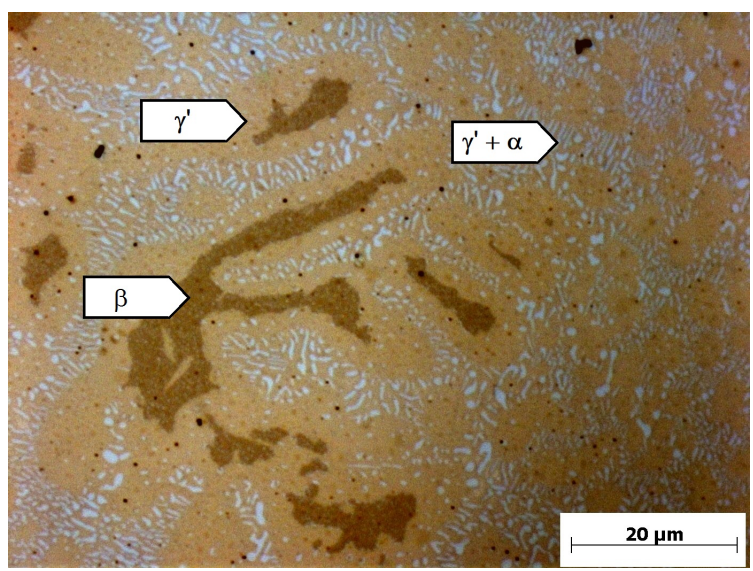

(c)

Figure 3(a) shows the micrograph of the reference alloy after casting and homogenization. It consists of a dark brown dendritic phase with a content of $35 \%$, measured with optical image analysis, and a bright interdendritic phase. A similar microstructure has been found by Achar [20] and was there identified as 
the cubic $\beta$-NiAl (dark brown) and the fcc $\gamma-\mathrm{Ni}$ (bright). Considering the Thermo-Calc calculations and the work of Achar, the dark brown dendritic phase in Figure 3(a) can be identified as $\beta$-NiAl and the interdendritic phase as the $\gamma$-phase.

After heat treatment at $800^{\circ} \mathrm{C}$, a two-phase $\gamma^{\prime} / \alpha$-Cr microstructure was predicted by the calculations. The metallographic examination (Figure 3(b),(c)) shows that the $\beta$-phase is still existent in the microstructure. Furthermore, a light brown phase forms at the interface between the $\beta$-phase and the interdendritic area. The interdendritic area consists of a light brown phase with the same contrast as the margin-phase around the $\beta$-particles and small, bright precipitates. After $4 \mathrm{~h}$ of heat treatment (Figure 3(b)), small $\beta$-particles are completely converted to the light brown phase. At bigger $\beta$-particles, only a small margin of approximately $2 \mu \mathrm{m}$ thickness of the light brown phase has formed. Further heat treatment for $100 \mathrm{~h}$ showed that the light brown phase grows with longer heat-treatment time, while the $\beta$-particle size is reduced (Figure 3(c)). The white particles in the interdendritic areas can be identified as $\alpha$-Cr, since an EDX-analysis of the white particles shows a Cr-content of $>60 \%$. Considering the poor resolution of EDX and the influence of the surrounding material, the Cr-content is even higher than measured. An EDX-analysis of the light brown phase shows an Al-content of $11.1 \% \pm 0.9 \%$, in agreement with the calculated Al-content of the $\gamma^{\prime}$-phase of $12 \%$. Hence, the light brown phase can be identified as $\gamma^{\prime}$, agreeing with the work of Achar [20]. The $\beta$-phase is still existent in the microstructure in contrast to the calculation, but the heat treatment for $100 \mathrm{~h}$ suggests that further heat treatment will lead to a complete conversion of the $\beta$-particles into $\gamma^{\prime}$ and $\alpha$-Cr.

\subsection{Increasing $\mathrm{Cu}$-Content}

For a rocket-engine application, the bond-coat alloy has to be modified by adding copper, as mentioned above. A copper-content of $30 \%$ was set as a starting point for further alloy development, because the coefficient of thermal expansion (CTE) was expected to be in the range of the copper substrate's CTE (see the Introduction). To investigate the influence of copper on the microstructure of $\mathrm{NiCrAl}$ alloys, the reference alloy examined above was modified by adding $30 \%$ copper.

The Thermo-Calc calculations for this alloy (Figure 1(b)) show a first solidifying $\alpha$-chromium and $\beta$-NiAl phase and a $\gamma^{\prime}$-phase solidifying at $1200^{\circ} \mathrm{C}$. Below $980{ }^{\circ} \mathrm{C}$, a $\gamma$-phase forms at the expense of the $\gamma^{\prime}$-phase. Compared to the calculations for the $\mathrm{Cu}$-free alloy, the $\beta$-phase is still the NiAl-phase, with a calculated chromium and copper content below $5 \mathrm{wt} \%$. The $\gamma$ '-phase contains now 30\% to $40 \%$ copper, depending on the temperature, while the $\gamma$-phase consists of more than $90 \%$ copper (see Figure 4). The microstructure of this alloy after homogenization is shown in Figure 5(a). It consists of a dark brown dendritic phase with bright particles in a light-brown matrix. Due to the morphology of the phases, it can be expected that the dark brown phase and the white particles solidify at higher temperatures than the light brown phase. The white particles were identified with EDX as chromium precipitates (see Figure 6). The light brown interdendritic phase has a measured composition similar to the calculated composition of the $\gamma^{\prime}$-phase at $1000^{\circ} \mathrm{C}$ (Figure $4(\mathrm{a})$ ). The dark brown phase has a measured composition very different from the calculated composition of the $\beta$-phase, but solidifies dendritically like the $\beta$-phase in the calculation. Furthermore, a $\beta$-phase has been observed elsewhere 
in the $\mathrm{Ni}-\mathrm{Cu}-\mathrm{Al}$ ternary system at $900{ }^{\circ} \mathrm{C}$, even at aluminum contents below $10 \%$ [21]. Hence, it can be assumed that the dark brown phase is actually $\beta$.

Figure 4. Phase compositions of the alloy $\mathrm{Ni}-30 \% \mathrm{Cu}-22 \% \mathrm{Cr}-10 \% \mathrm{Al}$ : measured with EDX and calculated with Thermo-Calc. (a) Calculated phase-compositions and measured compositions at $1000^{\circ} \mathrm{C}$; (b) calculated phase-compositions and measured compositions at $800^{\circ} \mathrm{C}$. $\gamma$ and $\gamma^{\prime}$ in the interdendritic area could not be analyzed separately due to the poor resolution of EDX.

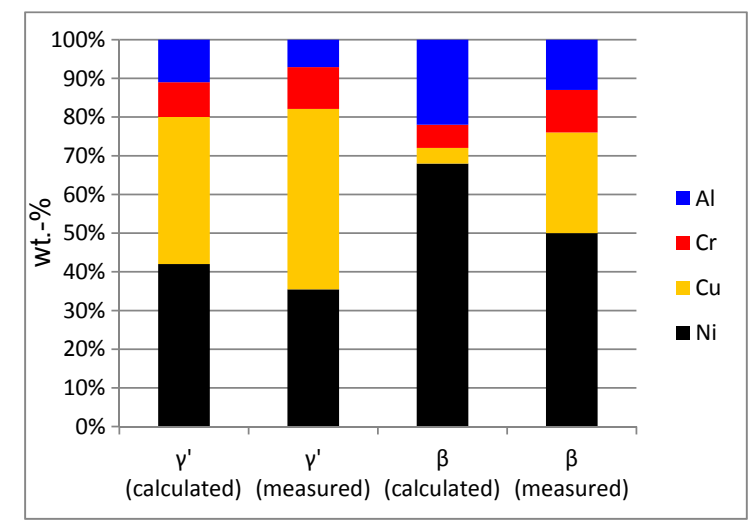

(a)

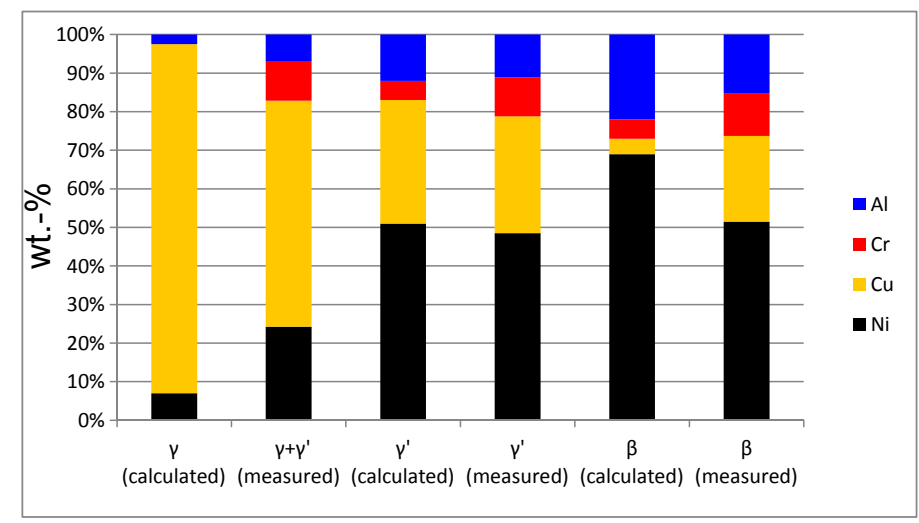

(b)

After heat treatment at $800^{\circ} \mathrm{C}$ (Figure 5), a light brown phase forms within the interdendritic $\gamma^{\prime}$-phase. Due to the poor resolution of the EDX-measurements, this phase could not be analyzed without the influence of the surrounding $\gamma^{\prime}$-phase. The measured composition of these two phases $\left(\gamma+\gamma^{\prime}\right.$ in Figure 4(b)) seems to be a mixture between the calculated composition of the $\gamma$ and $\gamma^{\prime}$-phase. Hence, it can be assumed that at $800^{\circ} \mathrm{C}$, a $\gamma$-phase precipitates within the interdendritic $\gamma^{\prime}$-phase, agreeing with the Thermo-Calc calculations in Figure 1(b). Furthermore, a margin around the dark particles was observed at $800^{\circ} \mathrm{C}$, which grows bigger with increasing heat-treatment time. Comparing the location of the small white chromium-particles after homogenization (Figure 5(a)) and after heat treatment at $800{ }^{\circ} \mathrm{C}$ (Figure 5), the margin seems to form only out of the $\beta$-phase. EDX-measurements at the margin phase show good agreement with the calculated composition of the $\gamma^{\prime}$-phase (Figure 4(b)).

Summing up, the Thermo-Calc calculations show a qualitative agreement with the observed microstructure. Only the quantitative values of phase-composition and fractions differ from the observed values. The reference-alloy with $30 \%$ copper consists of a large amount of $\beta$-, $\alpha$ - and $\gamma^{\prime}$-phase in the homogenized state. At $800^{\circ} \mathrm{C}$, the $\gamma^{\prime}$-phase forms out of the $\beta$-phase. This phase transition will lead to a volumetric change due to the different crystallographic structure [14]. This volumetric change might cause internal stresses. In standard NiCrAlY-alloys, like $\mathrm{Ni}-22 \% \mathrm{Cr}-10 \% \mathrm{Al}$, this has not to be considered, because the phase reaction takes place at $985^{\circ}$ (see Section 3.1). Furthermore, the CTE of $\alpha$ $\left(9 \times 10^{-6} \mathrm{~K}^{-1}\right.$ at $600{ }^{\circ} \mathrm{C}$ and $10 \times 10^{-6} \mathrm{~K}^{-1}$ at $\left.800^{\circ} \mathrm{C}\right)$ [8] is very low compared to the surrounding $\gamma^{-}$, $\beta$ - and $\gamma^{\prime}$-phase $\left(>15 \times 10^{-6} \mathrm{~K}^{-1}\right.$ at $600^{\circ} \mathrm{C}$ and $\left.800^{\circ} \mathrm{C}\right)[8,22]$ and will cause additional internal stresses and lower the resulting CTE of the alloy due to mixture rules. For further alloy development, it might be therefore necessary to reduce the amount of $\beta$ and $\alpha$-phase. 
Figure 5. Optical micrograph of the alloy $\mathrm{Ni}-30 \% \mathrm{Cu}-22 \% \mathrm{Cr}-10 \% \mathrm{Al}$ after different heat treatments, not etched. (a) Homogenization $\left(1000^{\circ} \mathrm{C}, 4 \mathrm{~h}\right)$; (b) $800^{\circ} \mathrm{C}, 4 \mathrm{~h}$; (c) $800^{\circ} \mathrm{C}, 100 \mathrm{~h}$.

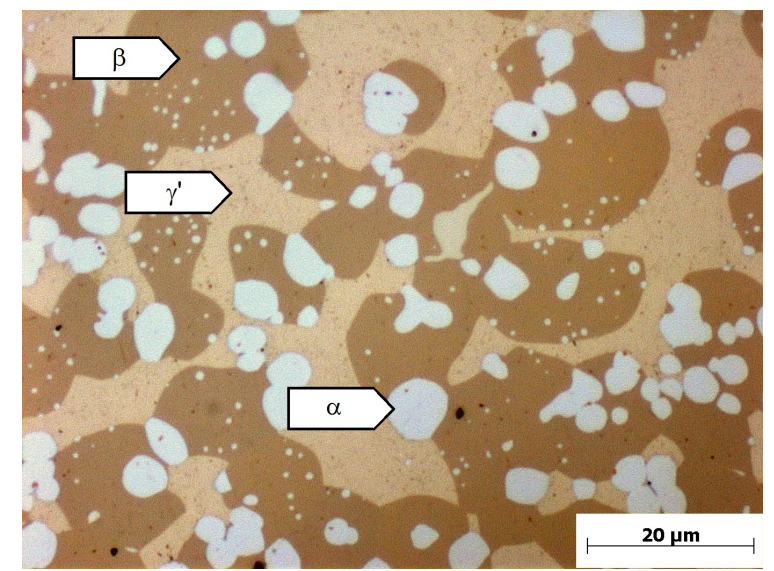

(a)

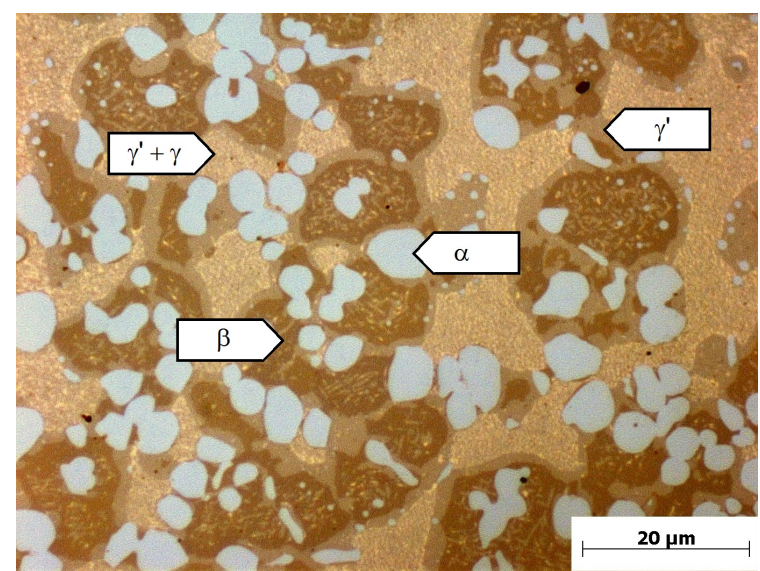

(b)

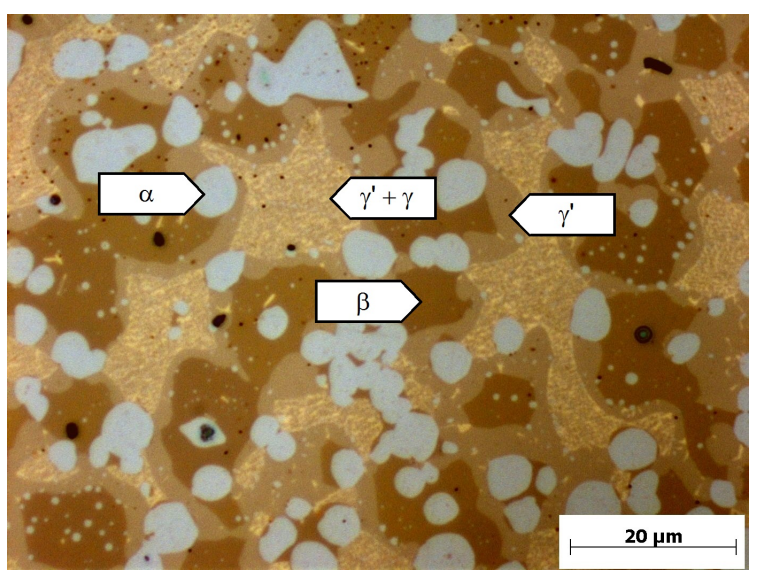

(c)

Figure 6. SEM-image of the same sample as in Figure 5(a). (a) Back scattered electrons; (b) X-ray signals of $\mathrm{Cr}-\mathrm{K} \alpha$.

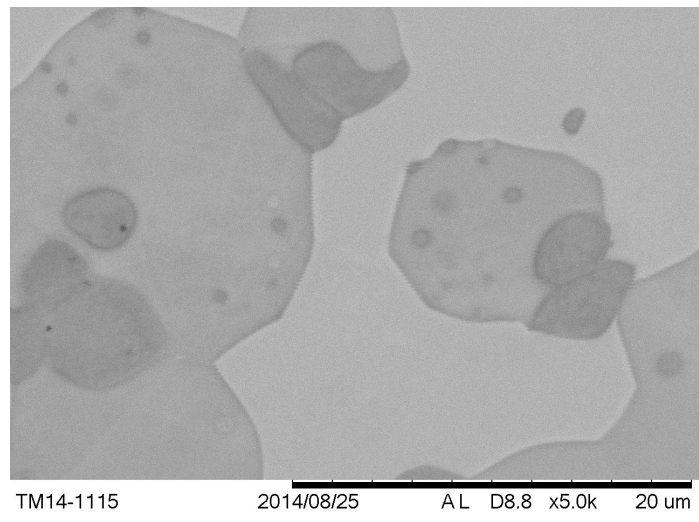

(a)

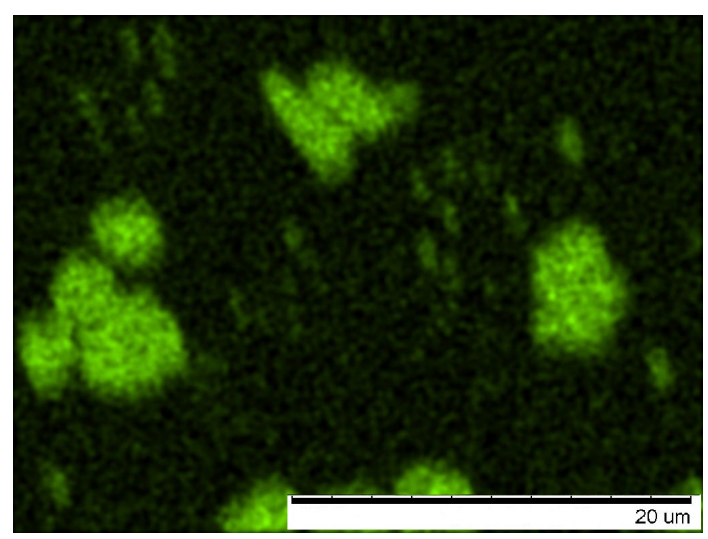

(b) 


\section{2. $\mathrm{Ni}-30 \% \mathrm{Cu}-22 \% \mathrm{Cr}$}

The reference alloy has been modified by adding $30 \% \mathrm{Cu}$ in the previous section, where an inappropriate amount of $\alpha$ - and $\beta$-phase was found, which has to be reduced in further alloy development. The easiest way to eliminate the $\beta$-phase in the microstructure is to reduce the aluminum content of the alloy.

The Thermo-Calc calculations in Figure 7 with the Alloy $\mathrm{Ni}-30 \% \mathrm{Cu}-22 \% \mathrm{Cr}$ and variable $\mathrm{Al}$-content showed that an Al-content below $8 \%$ prevents the formation of the $\beta$-phase. According to the calculations, a further reduction of the Al-content below $4 \%$ leads to the formation of a second, $\mathrm{Cu}$-rich $\gamma_{2}$-phase. Since most of the copper is dissolved in this $\gamma_{2}$-phase, the Ni-rich $\gamma_{1}$-phase is able to dissolve the chromium. Furthermore, the loss of aluminum increases the total amount of the $\gamma_{1}$-phase, so that the $\alpha$-Cr-phase destabilizes with the lower Al-content of the alloy. Therefore, one approach for the coating development was to investigate a coating alloy without aluminum, in this case the alloy $\mathrm{Ni}-30 \% \mathrm{Cu}-22 \% \mathrm{Cr}$. Although NiCrAlY bond-coats originally protect the substrate against oxidation by forming a dense Al-oxide layer, it is assumed that the Al-free alloy will form a Cr-oxide layer, which will be sufficient for the short-time hot-gas exposure in rocket engines [12].

Figure 7. Pseudobinary phase diagram calculated by Thermo-Calc of the alloy $\mathrm{Ni}-30 \% \mathrm{Cu}-22 \% \mathrm{Cr}$ with variable Al-content. The stable phases are marked with their symbol, phase boundaries with the corresponding color.

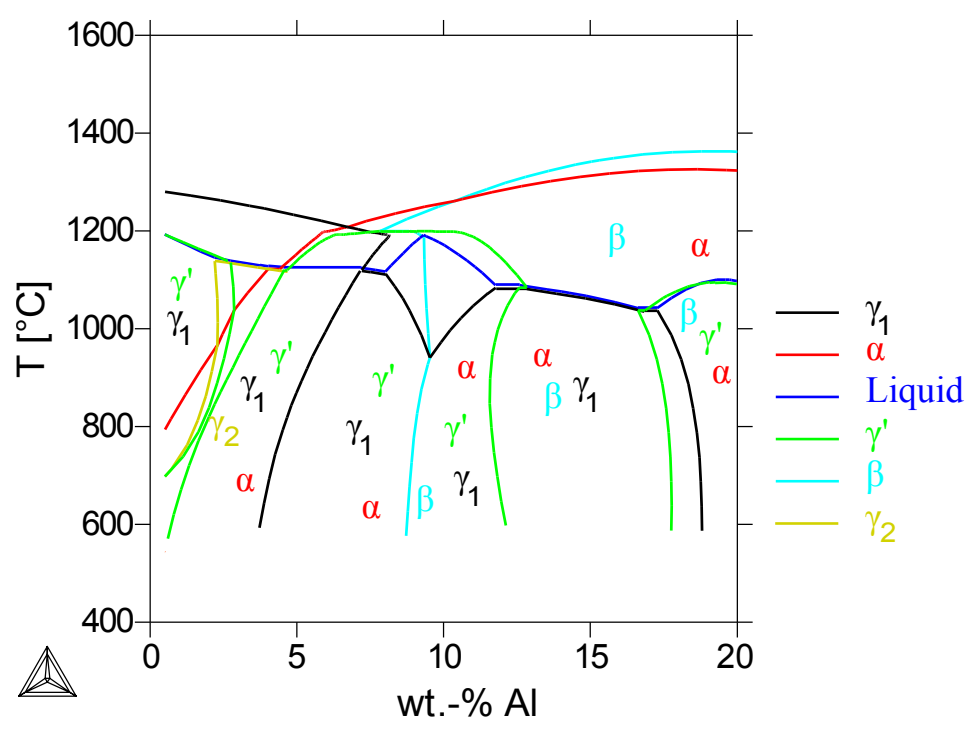

The DSC measurements of the Al-free alloy showed no detectable phase reaction below $1140{ }^{\circ} \mathrm{C}$. The solidus temperature is $1255^{\circ} \mathrm{C}$.

The microstructure after annealing at $1000^{\circ} \mathrm{C}$ and etching with molybdic acid is shown in Figure 9(a). It consists of a dendritic phase and an interdendritic phase, which is etched by molybdic acid. The fraction of the phases was measured via optical image analysis; the dendritic phase has a fraction of approximately $70 \%$, agreeing with the calculated value for the first solidifying Ni-rich $\gamma_{1}$-phase. The chemical composition of the dendritic phase measured with EDX is similar to the calculated composition of $\gamma_{1}$, and the measured composition of the interdendritic phase agrees with the calculation of the $\gamma^{\prime}$-phase, respectively (see Figure 10(a)). 
The Thermo-Calc calculation of the alloy $\mathrm{Ni}-30 \% \mathrm{Cu}-22 \% \mathrm{Cr}$ (Figure 8) showed a two-phase system at temperatures of $800^{\circ} \mathrm{C}$ and $1000^{\circ} \mathrm{C}$ : a first solidifying Ni-rich $\gamma_{1}$-phase and a second $\mathrm{Cu}$-rich $\gamma^{\prime}$-phase, solidifying at lower temperatures. The $\gamma^{\prime}$-phase converts into a $\gamma_{2}$-phase below $700{ }^{\circ} \mathrm{C}$. The formation of the $\alpha$-Cr phase is calculated only at temperatures below $750{ }^{\circ} \mathrm{C}$, while in the ternary phase diagram [23], the Cr-phase is even present at temperatures above $900{ }^{\circ} \mathrm{C}$.

Figure 8. Thermo-Calc calculations for the alloy $\mathrm{Ni}-30 \% \mathrm{Cu}-22 \% \mathrm{Cr}$.

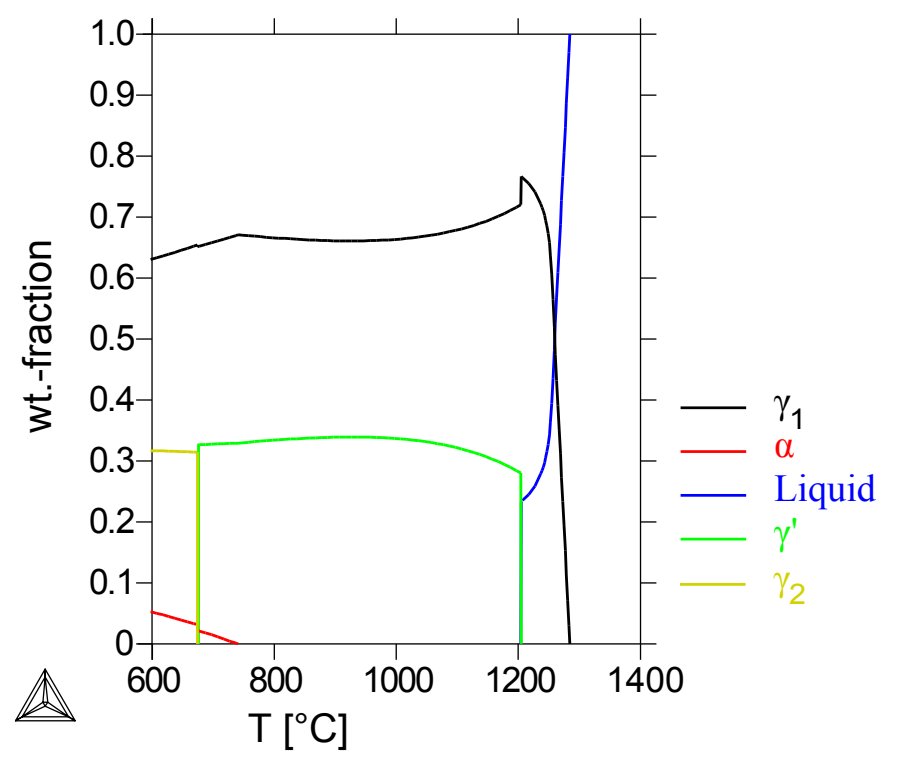

Figure 9. SEM-images (secondary electrons) of the alloy $\mathrm{Ni}-30 \% \mathrm{Cu}-22 \% \mathrm{Cr}$ after different heat treatments. Etched with molybdic acid. (a) Homogenization $\left(1000^{\circ} \mathrm{C}, 4 \mathrm{~h}\right)$; (b) $800^{\circ} \mathrm{C}$, $4 \mathrm{~h}$, plate-shaped precipitates in the dendritic area; (c) $800^{\circ} \mathrm{C}, 4 \mathrm{~h}$, spherical precipitates in the interdendritic area.

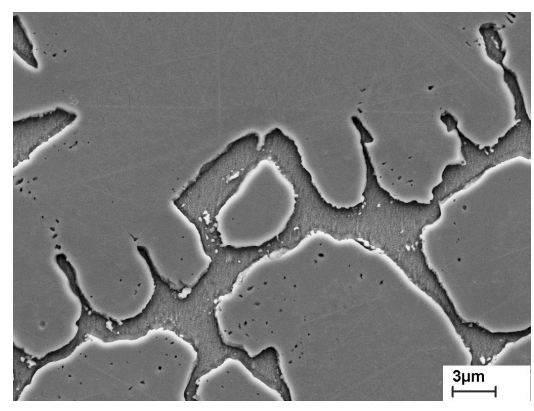

(a)

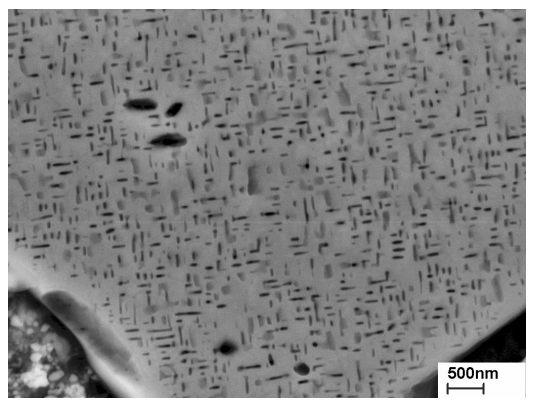

(b)

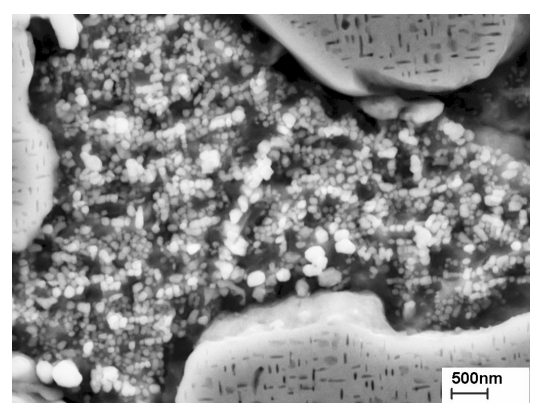

(c)

After heat treatment at $800{ }^{\circ} \mathrm{C}$ (Figure 9(b)), plate-shaped precipitates in the $\gamma_{1}$-phase were observed, which are etched by molybdic acid. In the interdendritic area, spherical precipitates are formed, which are not etched by molybdic acid. Due to the small particle-size, no EDX analysis was possible, since the resolution of EDX is limited to the micrometer scale. The Thermo-Calc calculations showed a decrease of $\mathrm{Cu}$ - and an increase of Ni-content in the $\gamma_{1}$-phase with lower temperatures (Figure 10(b)). Therefore, a Cu-rich phase may form out of the $\gamma_{1}$-phase by heat treatment at $800^{\circ} \mathrm{C}$. Since the precipitates in Figure 9(b) are coherent and no phase transition is predicted, it can be assumed that this is the $\mathrm{Cu}$-rich 
$\gamma^{\prime}$-phase, like in the interdendritic area at $1000^{\circ} \mathrm{C}$. For the interdendritic area, the precipitation of a $\mathrm{Ni}$-rich $\gamma_{1}$-phase could be assumed analogical.

Finally, the hardness of the alloy was measured. After annealing at $1000^{\circ} \mathrm{C}$, the alloy has nearly the same hardness (154 HV 1) as after heat treatment at $800^{\circ} \mathrm{C}(158 \mathrm{HV} 1)$. Hence, the nanoscale precipitates in the heat treated sample do not harden the material, so they must be coherent with a crystallographic structure and lattice parameter very similar to the matrix material. However, this is in conflict with the shape of the precipitates in the $\gamma_{1}$-phase, as one would expect a spherical or cubic shape of the precipitates in the absence of a lattice parameter misfit [14]. Thus, further work has to take place to elucidate the precipitation reaction taking place at $800^{\circ} \mathrm{C}$.

Figure 10. Phase compositions of the alloy $\mathrm{Ni}-30 \mathrm{Cu}-22 \% \mathrm{Cr}$ : measured with EDX and calculated with Thermo-Calc. (a) Calculated phase-compositions vs. measured compositions at $1000^{\circ} \mathrm{C} ;(\mathbf{b})$ calculated phase-compositions at $800^{\circ} \mathrm{C}$ and $1000^{\circ} \mathrm{C}$.

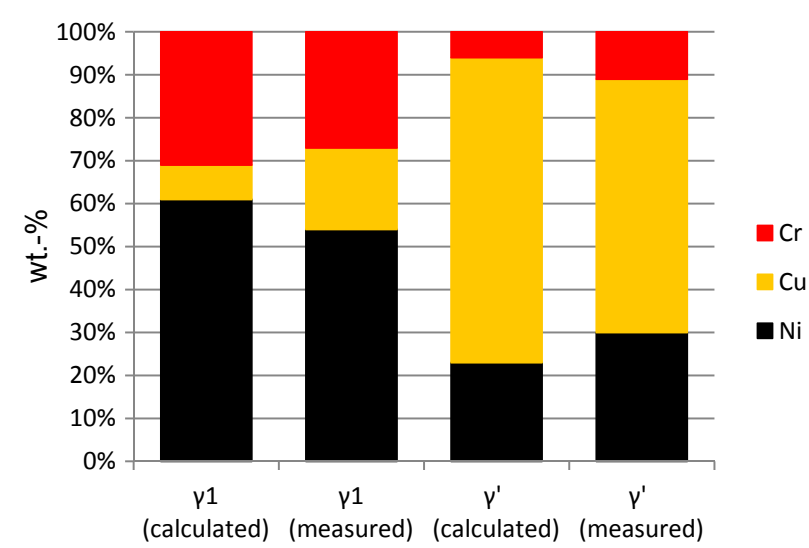

(a)

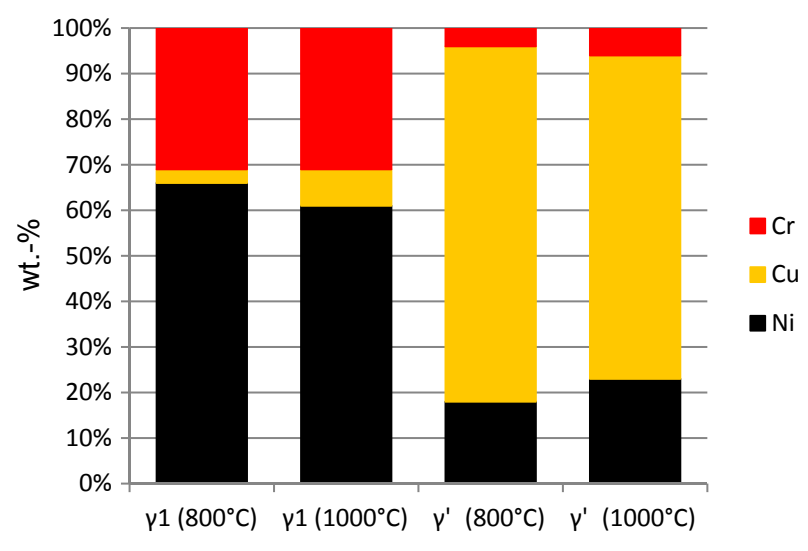

(b)

\section{3. $\mathrm{Ni}-30 \% \mathrm{Cu}-6 \% \mathrm{Al}-5 \% \mathrm{Cr}$}

In the previous section, an alloy without $\mathrm{Al}$ was investigated, where no $\alpha$ - and $\beta$-phase was observed. Although the $\mathrm{Al}$ might not be necessary in TBC-applications in rocket engines, this has not been demonstrated experimentally, so another possibility has to be considered, where an appropriate amount of $\mathrm{Al}$ is left to form an Al-oxide layer. In standard TBC-applications, the BC has to bring a large amount of $\mathrm{Al}$ and $\mathrm{Cr}$ to ensure a dense oxide layer over a long time, while the short heat exposure time in rocket engines does not make a large reservoir of $\mathrm{Al}$ and $\mathrm{Cr}$ necessary. To prove this experimentally, the $\mathrm{Ni}-30 \% \mathrm{Cu}$-alloy with $\mathrm{Cr}$ and $\mathrm{Al}$ content alike superalloys, in this case $6 \% \mathrm{Al}$ and $5 \% \mathrm{Cr}$, was investigated.

The Thermo-Calc calculations shown in Figure 11 predict a two-phase $\gamma_{1} / \gamma_{2}$-microstructure with the formation of $\gamma^{\prime}$ below $1100^{\circ} \mathrm{C}$. Below $900^{\circ} \mathrm{C}$, a $\gamma / \gamma^{\prime}$-microstructure is formed. 
Figure 11. Thermo-Calc calculations for the alloy $\mathrm{Ni}-30 \% \mathrm{Cu}-6 \% \mathrm{Al}-5 \% \mathrm{Cr}$.

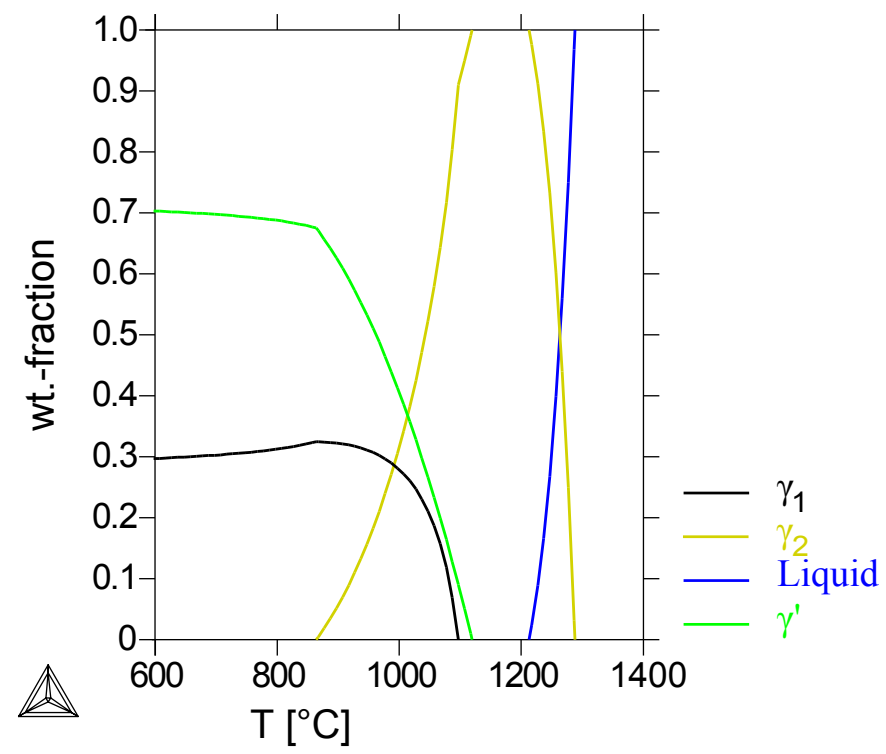

Figure 12. SEM-images (secondary electrons) of the alloy $\mathrm{Ni}-30 \% \mathrm{Cu}-6 \% \mathrm{Al}-5 \% \mathrm{Cr}$ after different heat treatments. Etched with Adler-reagent. (a) $800^{\circ} \mathrm{C}, 100 \mathrm{~h}$; (b) $900{ }^{\circ} \mathrm{C}, 100 \mathrm{~h}$; (c) $950{ }^{\circ} \mathrm{C}, 100 \mathrm{~h} ;(\mathbf{d}) 1000^{\circ} \mathrm{C}, 100 \mathrm{~h}$.

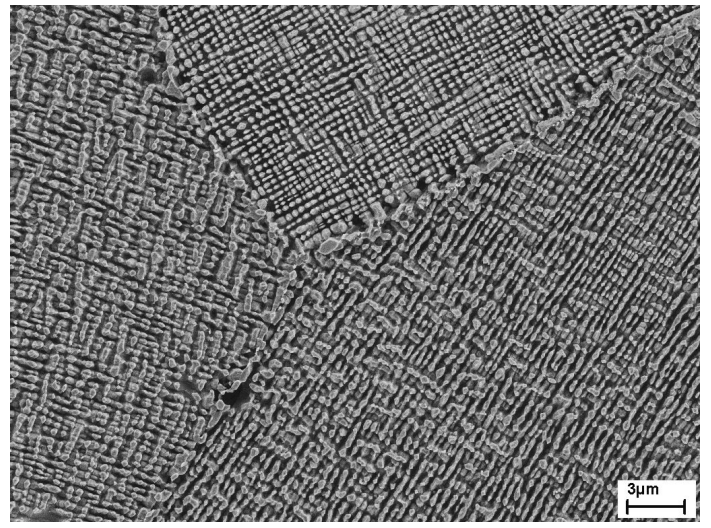

(a)

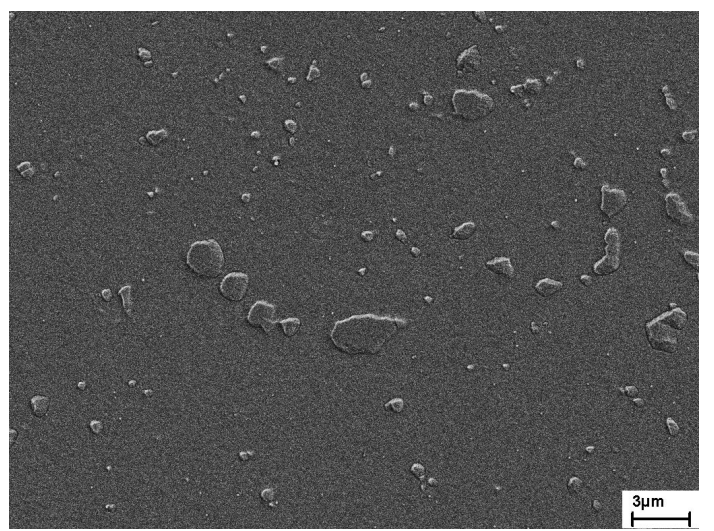

(c)

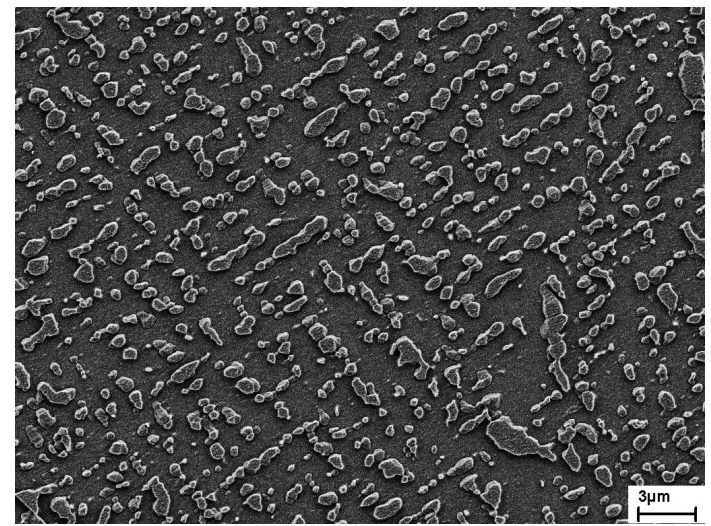

(b)

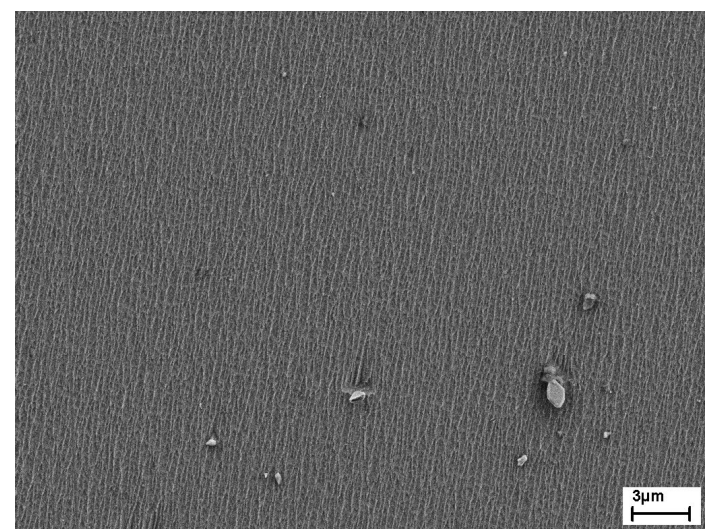

(d) 
Figure 12 shows the microstructure after different heat treatments. At $1000{ }^{\circ} \mathrm{C}$, the material is nearly homogeneous with only a few precipitates with a size of approximately $1 \mu \mathrm{m}$. At lower temperatures, more of the second phase precipitates up to a volume fraction of approximately $50 \%$ at $800{ }^{\circ} \mathrm{C}$. At $900{ }^{\circ} \mathrm{C}$ and below, the particles align themselves in a continuous pattern over the entire grain, so the precipitates must be coherent to the matrix phase. Though the resolution of EDX is in the range of the particle size at $950^{\circ} \mathrm{C}$, the measurements showed a higher $\mathrm{Al}$-content and lower $\mathrm{Cu}$-content in the precipitates compared to the matrix. Considering the Thermo-Calc calculations and the fact that the second phase has a higher $\mathrm{Al}$-content than the matrix and precipitates coherently, the microstructure below $1000{ }^{\circ} \mathrm{C}$ can be identified as $\gamma / \gamma^{\prime}$.

Calorimetric measurements show a reaction with small latent heat between $700{ }^{\circ} \mathrm{C}$ and $1000{ }^{\circ} \mathrm{C}$, related to the precipitation of the $\gamma^{\prime}$-phase. The solidus temperature of the alloy is $1260{ }^{\circ} \mathrm{C}$.

Furthermore, the coefficient of thermal expansion was measured. Figure 13 shows the CTE related to room temperature of the alloy $\mathrm{Ni}-30 \% \mathrm{Cu}-6 \% \mathrm{Al}-5 \% \mathrm{Cr}$ compared to the CTE of NiCrAlY-alloys used in previous studies and copper as the substrate. The CTE of the NiCuCrAl-alloy is about $2 \times 10^{-6} \mathrm{~K}^{-1}$ below the $\mathrm{CTE}$ of copper at room temperature and at $800^{\circ} \mathrm{C}$. In the range of $300^{\circ} \mathrm{C}$ to $800{ }^{\circ} \mathrm{C}$, the $\mathrm{CTE}$ is up to $5 \times 10^{-6} \mathrm{~K}^{-1}$ below the CTE of the Cu-alloy. At higher temperatures, the CTE-difference is even lower than $2 \times 10^{-6} \mathrm{~K}^{-1}$. However, the CTE-difference between $\mathrm{CuNiCrAl}$ and the copper substrate will be lower compared to the NiCrAlY-alloy used in previous studies. The lower value of the CTE below $800^{\circ} \mathrm{C}$ is probably caused by the forming/dissolution of the $\gamma^{\prime}$-phase.

Figure 13. Coefficient of thermal expansion related to room temperature of $\mathrm{Ni}-30 \% \mathrm{Cu}-6 \% \mathrm{Al}-5 \% \mathrm{Cr}, \mathrm{Cu}[24]$ and plasma-sprayed NiCrAlY [7].

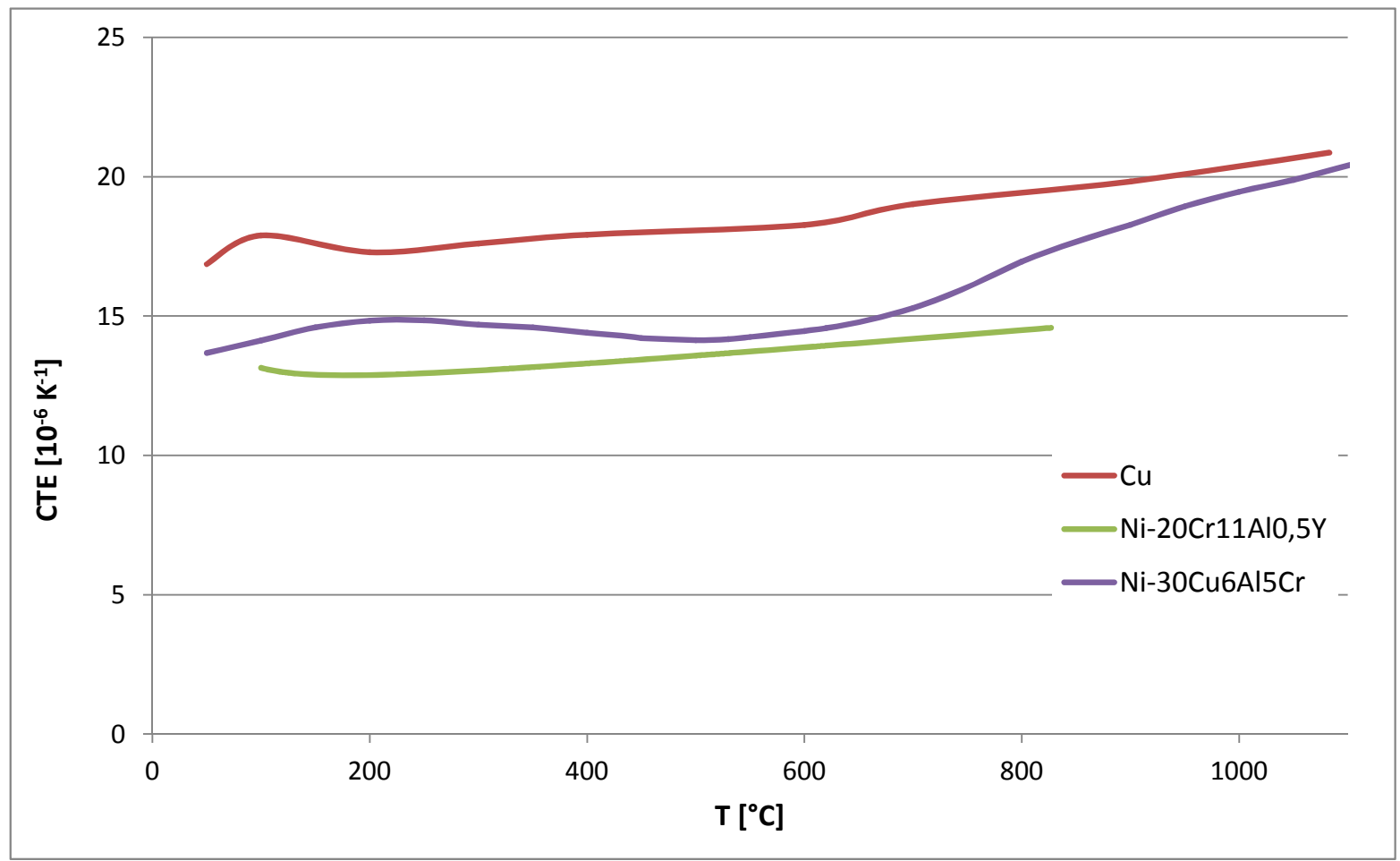




\section{Materials and Methods}

CALPHAD calculations were carried out with the software-package, Thermo-Calc [17], and the TTNI7-database. Although the database contains the involved elements and more than 30 possible phases, it is optimized to calculate Ni-based superalloys. Because a $\mathrm{Cu}$-content of $30 \%$ is unusual for these alloys, the calculated phase compositions can only be considered as estimates and have to be verified experimentally.

For experimental investigation, the chosen alloys (see Table 1) were prepared using a $\mathrm{Cu}-30 \% \mathrm{Ni}$ (wt\%) pre-alloy and $\mathrm{Cu}, \mathrm{Ni}, \mathrm{Cr}, \mathrm{Al}$ raw materials in a plasma-beam cold hearth melter and cast as rods with a diameter of $13 \mathrm{~mm}$. The samples were subsequently homogenized at $1000^{\circ} \mathrm{C}$ for $4 \mathrm{~h}$. To evaluate the influence of $\mathrm{Cu}$ on the microstructure of NiCrAl-alloys, the samples were analyzed after homogenizing and after heat treatment at $800^{\circ} \mathrm{C}$ for $4 \mathrm{~h}$ and $100 \mathrm{~h}$, respectively. For the alloy $\mathrm{Ni}-30 \% \mathrm{Cu}-6 \% \mathrm{Al}-5 \% \mathrm{Cr}$, additional heat-treatments at $900{ }^{\circ} \mathrm{C}, 950{ }^{\circ} \mathrm{C}$ and $1000^{\circ} \mathrm{C}$ were carried out for $100 \mathrm{~h}$. All samples were quenched in water after every heat treatment.

Table 1. Compositions of the alloys investigated in this work (in wt $\%$ ).

\begin{tabular}{cccc}
\hline Nickel & Copper & Chromium & Aluminum \\
\hline 68 & -- & 22 & 10 \\
38 & 30 & 22 & 10 \\
48 & 30 & 22 & -- \\
59 & 30 & 5 & 6 \\
\hline
\end{tabular}

Optical microscopy, scanning electron microscopy (SEM) and energy-dispersive X-ray spectroscopy (EDX) were carried out to investigate the microstructure. Some samples were etched with molybdic acid reagent [18] consisting of $100 \mathrm{~mL} \mathrm{H}_{2} \mathrm{O}$ (dest.), $100 \mathrm{~mL} \mathrm{HNO}_{3}$ (65\%), $100 \mathrm{~mL} \mathrm{HCl}(37 \%)$ and $3 \mathrm{~g} \mathrm{MoO}_{3}$. The alloy $\mathrm{Ni}-30 \% \mathrm{Cu}-6 \% \mathrm{Al}-5 \% \mathrm{Cr}$ was etched with the Adler-reagent (3 g copper-ammonium-chloride, $25 \mathrm{~mL} \mathrm{H}_{2} \mathrm{O}$ (dest.), $50 \mathrm{~mL} \mathrm{HCl}$ and $15 \mathrm{~g}$ Iron(III)-chloride [19]).

Phase transitions and melting temperatures were identified by differential scanning calorimetry (DSC) using a Netzsch STA 449F3 calorimeter. The samples were homogenized and then heat-treated for $4 \mathrm{~h}$ at $800{ }^{\circ} \mathrm{C}$ and turned to rods with a 4-mm diameter and a height of $1 \mathrm{~mm}$. They were heated up to $1370{ }^{\circ} \mathrm{C}$ with a heating-rate of $10 \mathrm{~K} \cdot \mathrm{min}^{-1}$ in an inert-gas atmosphere.

Dilatometric measurements were carried out to determine the coefficient of thermal expansion. The cylindrical sample with a diameter of $5 \mathrm{~mm}$ and a length of $43 \mathrm{~mm}$ was heated up from room temperature to $1120^{\circ} \mathrm{C}$ with a heating rate of $1 \mathrm{~K} \cdot \mathrm{min}^{-1}$.

The hardness was measured via Vickers indentation with a force of $9.8 \mathrm{~N}$ and an indentation time of $15 \mathrm{~s}$.

\section{Conclusions}

In this study, the influence of copper on the microstructure of $\mathrm{NiCrAl}$ bond-coat alloys has been analyzed. The reference alloy $\mathrm{Ni}-22 \% \mathrm{Cr}-10 \% \mathrm{Al}$ was modified by adding copper. Since a large amount 
of $\alpha-\mathrm{Cr}$ and $\beta-\mathrm{NiAl}$ was found in the microstructure at an amount of $30 \%$ copper, two alloys were investigated, where neither $\alpha$-Cr nor $\beta$-NiAl was expected: the aluminum-free alloy $\mathrm{Ni}-30 \% \mathrm{Cu}-22 \% \mathrm{Cr}$ and an alloy with a reduced $\mathrm{Al}$ and $\mathrm{Cr}$ content, $\mathrm{Ni}-30 \% \mathrm{Cu}-6 \% \mathrm{Al}-5 \% \mathrm{Cr}$. The main results can be summarized as follows:

- The addition of up to $30 \%$ copper to the reference $\mathrm{NiCrAl}$ alloy stabilizes the $\alpha$-Cr phase.

- The $\mathrm{Ni}-30 \% \mathrm{Cu}-22 \% \mathrm{Cr}$ alloy has a two-phase microstructure with a phase transition between $800^{\circ} \mathrm{C}$ and $1000^{\circ} \mathrm{C}$. This phase reaction has to be elucidated in further work.

- The Ni-30\% Cu-6\% Al-5\% Cr alloy has a fcc- $\gamma$ microstructure after homogenization. Below $1000^{\circ} \mathrm{C}$, a $\gamma / \gamma^{\prime}$-microstructure was observed.

- The CTE of the NiCuCrAl alloy is only about $2 \times 10^{-6} \mathrm{~K}^{-1}$ below the CTE of copper. The CTE-difference between copper substrate and the NiCuCrAl-bond coat will be lower compared to NiCrAlY bond-coats.

- Furthermore, Thermo-Calc has a sufficient reliability to allow the study of CuNiCrAl alloys.

\section{Acknowledgments}

Financial support has been provided by the Deutsche Forschungsgesellschaft (DFG) in the framework of the Sonderforschungsbereich Transregio 40, Teilprojekt D2. DSC-measurements were performed at the Institute for Material Science at the University of Rzeszów, Poland.

\section{Author Contributions}

To.F., Ta.F., J.R. and M.B. conceived and designed the experiments, T.F. performed the experiments, To.F., Ta.F., J.R. and M.B. analysed the data; To.F. wrote the paper.

\section{Conflicts of Interest}

The authors declare no conflict of interest.

\section{References}

1. Schloesser, J.; Kowollik, D.; Bäker, M.; Rösler, J.; Horst, P. Thermal Barrier Coatings in Rocket Engines-A Multiscale Simulation and Development Approach. In Sonderforschungsbereich/Transregio 40-Annual Report 2011; SFB/TRR 40: Garching, Germany, 2011; pp. 207-219.

2. Riccius, J.; Haidn, O.; Zametaev, E. Influence of Time Dependent Effects on the Estimated Life Time of Liquid Rocket Combustion Chamber Walls. In Proceedings of the 40th AIAA/ASME/SAE/ASEE Joint Propulsion Conference and Exhibit; AIAA: Fort Lauderdale, FL, USA, 2004.

3. Ogbuji, L. A table-top technique for assessing the blanching resistance of $\mathrm{Cu}$ alloys. Oxid. Met. 2005, 63, 383-399.

4. Ogbuji, L.U. Oxidation behavior of $\mathrm{Cu}-\mathrm{Cr}$ environmental barrier coatings on $\mathrm{Cu}-8 \mathrm{Cr}-4 \mathrm{Nb}$. Surf. Coat. Technol. 2005, 197, 327-335. 
5. Raj, S.V.; Ghosn, L.J.; Robinson, C.; Humphrey, D. High heat flux exposures of coated GRCop-84 substrates. Mater. Sci. Eng. A 2007, 457, 300-312.

6. Schloesser, J.; Bäker, M.; Rösler, J. Laser cycling and thermal cycling exposure of thermal barrier coatings on copper substrates. Surface Coat. Technol. 2011, 206, 1605-1608.

7. Taylor, T.; Walsh, P. Thermal Expansion of MCrAlY Alloys. Surface Coat. Technol. 2004, 177-178, 24-31.

8. Touloukian, Y.; Kirby, R.; Taylor, R.E.; Desai, P.D. Thermophysical Properties of Matter Alloys 12 - Thermal Expansion - Metallic Elements and Alloys; IFI/Plenum New York: Washington, DC, USA, 1975.

9. White, G.; Minges, M. Thermophysical Properties of Some Key Solids: An Update. Int. J. Thermophys. 1997, 18, 1269-1327.

10. Dies, K. Kupfer und Kupferlegierungen in der Technik; Springer-Verlag: Berlin/Heidelberg, Germany, 1967.

11. Sung, P.K.; Poirier, D.R. Estimation of densities and coefficients of thermal expansion of solid Ni-base superalloys. Mater. Sci. Eng. A 1998, 245, 135-141.

12. Schloesser, J.; Kowollik, D.; Bäker, M.; Rösler, J.; Horst, P. Sensitivity Analyses and Coating Development of Thermal Barrier Coatings in Rocket Engines. In Sonderforschungsbereich/ Transregio 40 - Annual Report 2012; SFB/TRR 40: Garching, Germany, 2012; pp. 209-218.

13. Massalski, T.B. Binary Alloy Phase Diagrams; American Society for Metals: Metals Park, OH, USA, 1986.

14. Bürgel, R.; Maier, H.J.; Niendorf, T. Handbuch Hochtemperatur-Werkstofftechnik; Vieweg Verlag: Wiesbaden, Germany, 2011.

15. Ma, K.; Tang, F.; Schoenung, J.M. Investigation into the effects of Fe additions on the equilibrium phase ccomposition, phase fractions and phase stabilities in the Ni-Cr-Al system. Acta Mater. 2010, 58, 1518-1529.

16. Durand-Charré, M. The Microstructure of Superalloys; Gordon and Breach Science Publishers: Amsterdam, The Netherlands, 1997.

17. Shi, P.; Sundman, B. Thermo-Calc Database Guide; Foundation of Computational Thermodynamics: Stockholm, Sweden, 2010.

18. Schumann, U.; DelGenovese, D.; Rösler, J. Auswahl der Ätzmedien für Ein- und Polykristalline Hochtemperaturwerkstoffe. Praktische Metallographie Sonderband 2004, 36, 269-274.

19. Schrader, A. Ätzheft; Gebr. Borntraeger: Berlin-Nikolassee, Germany, 1957.

20. Achar, D.; Munoz-Arroyo, R.; Singheiser, L.; Quadakkers, W.J. Modelling of phase distributions in MCrAlY coatings and their interactions with nickel based alloys. J. Phys. IV France 2004, 120, 231-238.

21. Köster, W.; Zwicker, U.; Moeller, K. Mikroskopische und röntgenographische Untersuchung zur Kenntnis des Systems Kupfer-Nickel-Aluminum. Zeitschrift für Metallkunde 1948, 39, 225-231.

22. Raj, S.; Palczer, A. Thermal Expansion of Vacuum Plasma Sprayed Coatings. Mater. Sci. Eng. A 2010, 527, 2129-2135.

23. Gupta, K.P. Phase Diagrams of Ternary Nickel Alloys; Indian Institute of Metals: Calcutta, India, 1990. 
24. Kupferinstitut, D., Ed. Kupferdatenblatt $\mathrm{CuCr} 1 \mathrm{Zr}$; Deutsches Kupferinstitut, Düsseldorf, Germany, 2005.

(C) 2014 by the authors; licensee MDPI, Basel, Switzerland. This article is an open access article distributed under the terms and conditions of the Creative Commons Attribution license (http://creativecommons.org/licenses/by/4.0/). 